\title{
COMMENTS FROM THE EDITOR
}

\section{DEPARTURE OF ASSOCIATE EDITOR}

n February 1, 1999, L. Henry Edmunds, Jr, will leave the editorial staff of the Journal as Associate Editor to join the editorial staff of the Annals of Thoracic Surgery as the Editor-designate. Hank has worked hard for the Journal, first on the Advisory Editorial Board and for the past 3 years as an Associate Editor. He has

J Thorac Cardiovasc Surg 1999;117:412

Copyright $\odot 1999$ by Mosby, Inc.

$0022-5223 / 99 \$ 8.00+0 \quad \mathbf{1 2 / 1 / 9 6 4 1 5}$ brought to this task a keen intellect, superb insight, and high standards, yet fairness. We will miss him and know he will serve our sister publication well.

To replace Hank we have asked Ralph Damianocurrent Advisory Editorial Board member-to serve as the new associate Editor, and he has accepted. Ralph brings to this endeavor an outstanding background, not only in clinical surgery but in investigative cardiothoracic surgery as well.

John A. Waldhausen, MD 